\title{
THE EFFECT OF STRETCH ON THE ELECTRICAL CONSTANTS OF MUSCLE FIBRE MEMBRANE
}

\author{
NOBUSADA ISHIKO AND MASAYASU SATO* \\ Department of Physiology, Kumamoto University Medical School, Kumamoto, Japan
}

It is known that by application of stretch to the muscle the heat production and $\mathrm{O}_{2}$ consumption of the resting muscle is increased (Feng, 1932), the rate of $\mathrm{CO}_{2}$ production rises (Eddy and Downs, 1921) and the cellular $\mathrm{Na}$ diminishes (Harris, 1954). According to Ling and Gerard (1949) the resting potential is not altered by stretch, but recent experiments of Ishiko $(1958,1959)$ clearly demonstrate a decrease in the resting potential. Martin (1954) reported the conduction velocity of muscle to be unaltered by the application of stretch, while many investigators found an increase in the conduction velocity (Wilska and Varjoranta, 1940; Inoue, 1955; Håkansson, 1957). These experimental results may suggest that the muscle fibre membrane suffers changes in the membrane capacitance and conductance with a change in length. The experiments which will be reported in the present paper, therefore deal with the effect of stretch on the membrane constants of muscle fibres of toads.

\section{METHODS}

Material. Sartorius, iliofibular and toe muscles, isolated from Japanese toads (Bufo vulgaris formosus), were used. The stretch experiments were carried out on the former two muscles, but not on the latter. The muscle was stretched in a saline bath, its normal length in situ being taken as $100 \%$. The membrane constants were measured in several muscle fibres at $100 \%$ length, in fibres at $130 \%$ length, and finally in muscle fibres relaxed again to $100 \%$. As it was difficult to get a significant difference in experimental results by stretching a muscle step by step, only a $130 \%$ stretch was examined.

Experimental procedure and circuits employed. The membrane constants were measured using 'square pulse analysis', by applying to the muscle flbre rectangular anodal currents of about $100 \mathrm{msec}$ duration through a microelectrode filled with $3 \mathrm{M} \mathrm{KCl}$; and recording the electrotonic potential either with another microelectrode inserted into the same fibre or with the same microelectrode. For recording membrane potential change, a d.c. amplifier connected with a cathode follower stage of low grid-current and of reduced grid-to-earth capacity

Received for publication September 13, 1959.

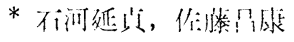


was used. The polarizing current through the microelectrode was measured by recording with another d.c. amplifier the potential drop across a resistor inserted between the Ringer bath and the earth.

The first method of passing currents through a microelectrode and of recording membrane potential change at three points of the muscle fibre with another microelectrode was the same as that adopted by Fatt and Katz (1951), and in the present experiment it was employed in measuring the membrane constants of sartorius muscle fibres. Impalement of the muscle fibre was made first with the potential electrode, and the current electrode was inserted into it at distances of about $50-100,500$ and $1000 \mu$ in no fixed order. In some cases, however, the resting potential diminished during successive impalements of the same muscle fibre; and these experiments were discarded. The current strength employed was about $5 \times 10^{-8} \mathrm{~A}$, which is well below the threshold strength of $1-2 \times 10^{-7} \mathrm{~A}$, and is of opposite polarity. The distance between the current and potential electrodes on the muscle fibre was measured by a binocular microscope of $48 \times$ magnification, and the fibre diameter was similarly measured in order to check the calculated value.

In order to measure the membrane constants of small muscle fibres, it was difficult to adopt the method described above, because these muscle fibres were easily depolarized by impalement with two microelectrodes. Therefore, in the experiments with $M$. iliofibularis and $M$. extens. long. digit. IV the method of employing one and the same microelectrode inserted into a muscle fibre for passing polarizing currents and for recording membrane potential change was used. For this purpose a 'bridge-method' was previously adopted by Koketsu and Nishi (1957); but in the present experiments the circuit designed by Ito (1957) for compensating the potential between the inside of the cell and the earth, and for cancelling the stimulating pulse, was employed. A schematic diagram of the circuit, which was modified by Ito (1958) from his original one, is shown in fig. 1. The potential appearing between the inside of the cell and the earth is compensated with a negative feed-back loop from the output of amplifier $(G)$, and the rectangular pulse from the square pulse generator $\left(E_{s}\right)$ is fed into one of the differential inputs of the $G$ amplifier. For reducing the time constant of the cathode follower stage the negative capacitance method described by MacNichol and Wagner (19j4) was used. The circuit described here could not be used for a large cell such as a sartorius muscle fibre, because in this muscle fibre a polarizing current of $5 \times 10^{-8} \mathrm{~A}$ is necessary to get a membrane potential change of sufficient magnitude, and with currents of such a strength it is impossible to cancel correctly the polarizing pulse from the pulse generator at the stage of the $G$ amplifier, because of electrode polarization. The currents used for polarizing iliofibular and toe muscles are about $10 \times 10^{-9} \mathrm{~A}$ and $6 \times 10^{-9} \mathrm{~A}$, respectively. Microelectrodes of $10-20 \mathrm{~m} \Omega$ resistance were employed in the experiments, because such electrodes do not show a nonlinear resistance character with a current of $10 \times 10^{-8} \mathrm{~A}$.

The procedure of the experiments using this compensating circuit is as follows: Before penetrating the muscle fibre with a microelectrode, potentials appearing between the Ringer bath and the earth, i.e. electrode potential and 


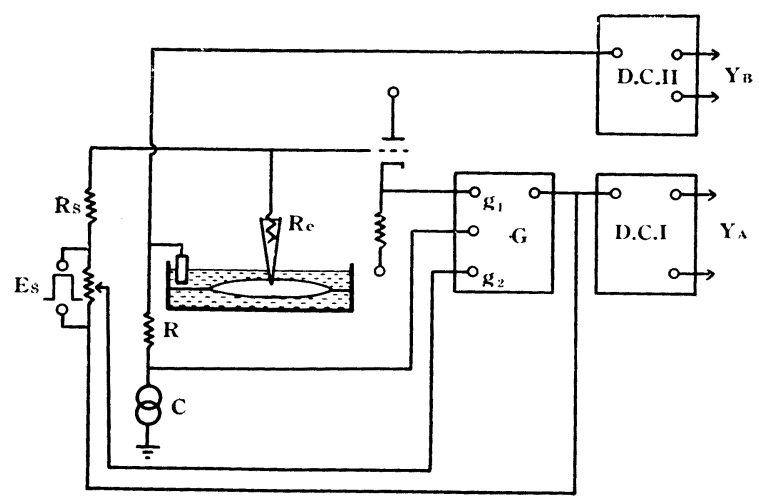

FIG. 1. The schematic diagram of the experimental arrangement with 'one electrode method'. $C$; voltage calibrator, D.C.I. and D.C.II.; d.c. amplifiers, $E_{s}$; square pulse generator, $G$; preamplifier of $100 \times$ amplification, $g_{1}$ and $g_{2}$; differential inputs of $G$ amplifier, $R$; resistor of $10 \mathrm{~K} \Omega$ for recording current strength, $R_{e}$; microelectrode resistance, $R_{s}$; resistor of $100 \mathrm{M} \Omega, Y_{A}$ and $Y_{B}$; double beam oscilloscope.

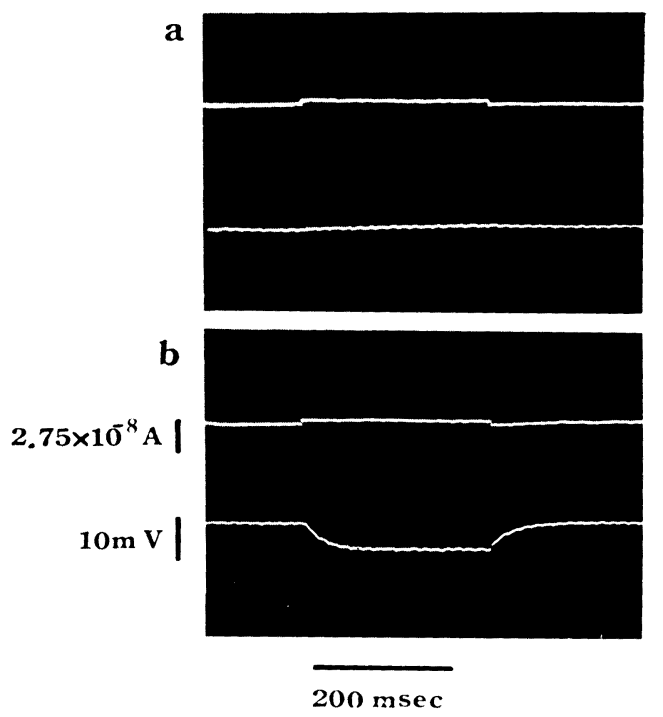

FIG. 2. $a$ : Oscillograph traces before impaling a muscle fibre with a microelectrode, after potentials from a square pulse generator and from the electrode are compensated. $b$ : An electrotonic potential produced in an fibre of $M$. extens. long. dight. IV with a current of about $7 \times 10^{-9} \mathrm{~A}$. In both records upper traces indicate current recording and lower ones potential recording. Voltage calibration: $10 \mathrm{mV}$, current calibration: $2.75 \times 10^{-8} \mathrm{~A}$, and time signal: $200 \mathrm{msec}$. 
that due to polarizing currents, were cancelled and the frequency characteristics of the preamplifier was adjusted so that an input time constant of about $100 \mu$ sec was obtained (fig. $2 a$ ); then the muscle fibre was impaled with a microelectrode, and a membrane potential change appeared suddenly (fig. $2 b$ ). The strength of the polarizing current remained unaltered before and after the penetration.

Method of analysis. The analysis of the electrotonic potential for calculating membrane constants from the electrotonic potentials obtained with the 'one microelectrode method' was the same as that employed by Koketsu and Nishi (1957). The time constant of the membrane $\left(\tau_{m}\right)$ was taken as either the time of decline of the electrotonic potential to $15 \%$ or that of its $85 \%$ rise (Hodgkin and Rushton, 1946; Fatt and Katz, 1951). Actually the time constant of the muscle fibre membrane measured at the rising and falling phases of the electrotonic potentials did not differ significantly (table 1), and therefore their mean values were taken. The diameter $(d)$ of the muscle fibre was measured with a binocular microscope of $48 \times$. The myoplasm resistance $R_{i}$ was calculated by putting $t$, temperature of the Ringer bath during the experiment, into Tamasige's empirical formula $R_{i}=500\left(1-0.055 t+0.0009 t^{2}\right)$ (Tamasige, 1950), instead of assuming $R_{i}$ to be $250 \Omega \mathrm{cm}$. as adopted conveniently by Fatt and Katz (1951) and Koketsu and Nishi (1957). From $d, R_{i}, \tau_{m}$, current strength $I$ and the final value $V$ of the electrotonic potential $\lambda, R_{m}$ and $C_{m}$ were calculated.

TABLE 1. Average Values of Time Constant of Muscle Fibre Membrane at Rising and Falling Phases of Electrotonic Potentials

\begin{tabular}{cc|c|c|c} 
Muscles & & No. of fibres & Time constant (msec.) \\
& & & Rise & Fall \\
\hline Iliofibularis & A & 14 & $18.8 \pm 1.3$ & $19.4 \pm 1.2$ \\
& B & 13 & $19.9 \pm 1.7$ & $19.5 \pm 1.6$ \\
& C & 13 & $17.9 \pm 0.6$ & $16.9 \pm 0.3$ \\
Extens. long. & A & 9 & $13.1 \pm 1.1$ & $11.7 \pm 1.0$ \\
digit. IV & B & 6 & $15.9 \pm 1.8$ & $16.6 \pm 0.4$ \\
& C & 13 & $17.9 \pm 0.6$ & $19.1 \pm 0.7$ \\
& & & & \\
\hline
\end{tabular}

refers to S.E. of the mean.

The analysis of the results on sartorius muscles obtained with the 'two microelectrodes' method is the same as that adopted by Fatt and Katz (1951). $\tau_{m}$ was calculated from the relation between the mean values of half times of rising and falling phases of electrotonic potentials and the distance $x$. $R_{i}$ was obtained similarly from Tamasige's formula, and $\lambda$ and $1 / 2\left(r_{m} r_{i}\right)^{1 / 2}$ were obtained directly from $x, V$ and $I$. Other constants including $d$ were calculated from these values. 
Ringer's solution. The ionic composition of the Ringer's solution used throughout this experiment was: $111 \mathrm{mM} \mathrm{NaCl}, 2.5 \mathrm{mM} \mathrm{KCl}, 1.8 \mathrm{mM} \mathrm{CaCl}_{2}$ and $2.4 \mathrm{mM} \mathrm{NaHCO}$.

The experiments were performed during the spring and summer of 1958 .

RESULTS

Membrane constants of muscle fibres of toads. The membrane constants were calculated in 69 muscle fibres from 3 sartorius muscles, in 73 fibres from 3 iliofibular muscles and in 28 fibres from 3 toe muscles. Average values of constants for individual muscles at $100 \%$ and $130 \%$ lengths are tabulated in tables 2 and 3 . The stretch experiment was not carried out on toe muscles; only the constants at a fixed length were measured.

It will be seen in table 2 that the calculated values of $d$ are consistent with those measured directly, indicating that the $R_{i}$ values calculated from $R_{i}=500\left(1-0.055 t+0.0009 t^{2}\right)$ are correct. If one assumes $R_{i}$ to be $250 \Omega \mathrm{cm}$., $R_{i}$ and $d$ in the tables should be multiplied by a factor of $\left(250 / R_{i}\right)^{1 / 2}$, and $C_{m}$ should be divided by the same factor. For example, calculated $d$ of muscle $B$ in table 2 will become $150 \mu$ and $135 \mu$ for $100 \%$ and $130 \%$ stretch respectively. These agree less well with the observed values. However, Yoshida (1958) reports that the diameter of sartorius muscles of Japanese toads varies between $125 \mu$ and $165 \mu$, and has its maximum popultion at $150 \mu$. Furthermore, when measuring the fibre diameter by microscopic observation, there is in general a tendency to underestimate it. Therefore it cannot be said here whether it is more correct to adopt the $R_{i}$ value calculated from Tamasige's empirical formula, or $250 \Omega \mathrm{cm}$. as assumend by several investigators (Fatt and Katz, 1951; Koketsu and Nishi, 1957). As it does not seem seriously to affect the comparison of $C_{m}$ and $R_{m}$ between relaxed and stretched states, the authors employed Tamasige's empirical formula for calculating $R_{i}$.

$\tau_{m}$ and $R_{m}$ of sartorius muscles $A$ and $B$ in table 2 show somewhat smaller values than those of sartorius muscle $C$ and other muscles. This might be due to the depolarization consequent on the insertion of two microelectrodes

TABLE 2. Average Values of Membrane Constants of Sartorius Muscle Fibres

\begin{tabular}{|c|c|c|c|c|c|c|c|c|c|c|c|}
\hline \multicolumn{4}{|c|}{$\begin{array}{l}\text { Temp. Muscle } \\
\text { stretch No. of } \\
\text { fibres }\end{array}$} & \multirow{2}{*}{$\begin{array}{c}d \\
\text { (obs.) } \\
(\mu)\end{array}$} & \multirow{2}{*}{$\begin{array}{l}\frac{1}{2}\left(r_{m} r_{i}\right)^{1 / 2} \\
\left(\times 10^{3} \Omega\right)\end{array}$} & \multirow{2}{*}{$\begin{array}{c}\lambda \\
(\mathrm{mm} .)\end{array}$} & \multirow{2}{*}{$\begin{array}{c}\tau_{m} \\
(\mathrm{msec} .)\end{array}$} & \multirow{2}{*}{$\begin{array}{c}d \\
\text { (calc.) } \\
(\ell)\end{array}$} & \multirow{2}{*}{$\begin{array}{c}R_{m} \\
\left(\Omega \cdot \mathrm{cm}^{2} .\right)\end{array}$} & \multirow{2}{*}{$\begin{array}{c}R_{i} \\
\Omega \bullet \mathrm{cm} .)\end{array}$} & \multirow{2}{*}{$\begin{array}{c}C_{m} \\
\left(u \mathrm{~F} / \mathrm{cm}^{2} .\right)\end{array}$} \\
\hline${ }^{\circ} \mathrm{C}$ & & $\%$ & & & & & & & & & \\
\hline 19 & A & $\begin{array}{l}100 \\
130\end{array}$ & $\begin{array}{l}7 \\
7\end{array}$ & $\begin{array}{r}104 \\
70\end{array}$ & $\begin{array}{l} \pm 4.6 \\
\pm 8.5\end{array}$ & & & $\begin{array}{l}98 \pm \\
86 \pm\end{array}$ & $\begin{array}{r}1110 \\
870\end{array}$ & 140 & \\
\hline 26 & B & $\begin{array}{l}100 \\
130\end{array}$ & $\begin{array}{l}11 \\
11\end{array}$ & $82 \pm$ & $\begin{array}{l}128 \pm 3.8 \\
132 \pm 3.6\end{array}$ & & & $\begin{array}{l}89 \pm \\
81 \pm\end{array}$ & $\begin{array}{l}1250 \pm \\
1040-\end{array}$ & 90 & $\begin{array}{l}7.1= \\
8.3=\end{array}$ \\
\hline 22 & C & $\begin{array}{l}100 \\
130\end{array}$ & $\begin{array}{l}11 \\
12\end{array}$ & & $\begin{array}{l}301 \pm 11.7 \\
420 \pm 5.1\end{array}$ & & $\begin{array}{l}11.0 \pm 0.3 \\
12.1 \pm 0.2\end{array}$ & $\begin{array}{l}66+1.4 \\
52+0.7\end{array}$ & $\begin{array}{l}2990= \\
2650=\end{array}$ & 115 & $\begin{array}{l}4.7= \\
4.5=\end{array}$ \\
\hline
\end{tabular}

\footnotetext{
\pm refers to S.E. of the mean.
} 
TABLE 3. Average Values of Membrane Constants of Iliofibular and toe Muscles

\begin{tabular}{|c|c|c|c|c|c|c|c|c|c|c|}
\hline \multicolumn{4}{|c|}{$\begin{array}{c}\text { Temp. Muscle } \\
\text { No. of Stretch } \\
\text { fibres }\end{array}$} & \multirow{2}{*}{$\begin{array}{c}d \\
(\mu)\end{array}$} & \multirow{2}{*}{$\begin{array}{l}\frac{1}{2}\left(r_{n i} r_{i}\right)^{1 / 2} \\
\left(\times 10^{3} \Omega\right)\end{array}$} & \multirow{2}{*}{$\begin{array}{c}\lambda \\
(\mathrm{mm} .)\end{array}$} & \multirow{2}{*}{$\begin{array}{c}\tau_{m} \\
(\mathrm{msec} .)\end{array}$} & \multirow{2}{*}{$\begin{array}{c}R_{m} \\
\left(\Omega \cdot \mathrm{cm}^{2} .\right)\end{array}$} & \multirow{2}{*}{$\left|\begin{array}{c}R_{i} \\
(\Omega \cdot \mathrm{cm} .)\end{array}\right|$} & \multirow{2}{*}{$\begin{array}{c}C_{m} \\
\left(\mu \mathrm{F} / \mathrm{cm}^{2} .\right)\end{array}$} \\
\hline${ }^{\circ} \mathrm{C}$ & & & $\%$ & & & & & & & \\
\hline \multicolumn{11}{|c|}{ M. iliofibularis } \\
\hline 22 & A & $\begin{array}{l}14 \\
13\end{array}$ & $\begin{array}{l}100 \\
130\end{array}$ & $\begin{array}{l}59 \pm 0.3 \\
44 \pm 0.2\end{array}$ & $\begin{array}{l}384 \pm 9.5 \\
566 \pm 11.3\end{array}$ & $\begin{array}{l}2.0 \pm 0.06 \\
1.6 \pm 0.04\end{array}$ & $\begin{array}{l}19.1 \pm 0.1 \\
21.4 \pm 0.5\end{array}$ & $\begin{array}{l}3190 \pm 211 \\
2910 \pm 144\end{array}$ & 110 & $\begin{array}{l}9.4 \pm 0.38 \\
9.3 \pm 0.31\end{array}$ \\
\hline 26 & B & $\begin{array}{l}13 \\
10\end{array}$ & $\begin{array}{l}100 \\
130\end{array}$ & $\begin{array}{l}59 \pm 1.1 \\
49 \pm 0.7\end{array}$ & $\begin{array}{l}307 \pm 7.1 \\
378 \pm 13.2\end{array}$ & $\begin{array}{l}1.8 \pm 0.01 \\
1.6 \pm 0.09\end{array}$ & $\begin{array}{l}19.7 \pm 0.5 \\
22.0 \pm 0.8\end{array}$ & $\begin{array}{l}2060 \pm 78 \\
1990 \pm 86\end{array}$ & 90 & $\begin{array}{l}10.2 \pm 0.18 \\
12.6 \pm 0.41\end{array}$ \\
\hline 26 & $\mathrm{C}$ & $\begin{array}{l}13 \\
10\end{array}$ & $\begin{array}{l}100 \\
130\end{array}$ & $\begin{array}{l}62 \pm 0.3 \\
53 \pm 0.3\end{array}$ & $\begin{array}{l}278 \pm 4.8 \\
339 \pm 3.3\end{array}$ & $\begin{array}{l}1.9 \pm 0.12 \\
1.7 \pm 0.06\end{array}$ & $\begin{array}{l}17.4 \pm 0.1 \\
17.2 \pm 0.2\end{array}$ & $\begin{array}{l}2170 \pm 86 \\
2030 \pm 116\end{array}$ & 90 & $\begin{array}{r}9.6 \pm 0.30 \\
11.2 \pm 0.54\end{array}$ \\
\hline \multicolumn{11}{|c|}{ M. extens. digit. long. IV } \\
\hline $\begin{array}{l}14 \\
14 \\
15\end{array}$ & $\begin{array}{l}\text { A } \\
\text { B } \\
\text { C }\end{array}$ & $\begin{array}{r}9 \\
6 \\
13\end{array}$ & & $\begin{array}{l}40 \pm 0.6 \\
44 \pm 1.5 \\
43 \pm 0.1\end{array}$ & $\begin{array}{l}975 \pm 35 \\
991 \pm 43 \\
800 \pm 19\end{array}$ & $\begin{array}{l}1.2 \pm 0.04 \\
1.5 \pm 0.03 \\
1.2 \pm 0.09\end{array}$ & $\begin{array}{l}12.5 \pm 0.4 \\
16.2 \pm 0.6 \\
18.5 \pm 0.4\end{array}$ & $\begin{array}{l}3074 \pm 184 \\
4300 \pm 115 \\
2850 \pm 123\end{array}$ & $\begin{array}{l}205 \\
205 \\
190\end{array}$ & $\begin{array}{l}5.7 \pm 0.13 \\
5.3 \pm 0.26 \\
8.3 \pm 0.30\end{array}$ \\
\hline
\end{tabular}

\pm refers to S.E. of the mean.

into the muscle fibre (Fatt and Katz, 1951; Ishiko, 1957). In general the membrane constants of muscle fibres of toads presented in tables 2 and 3 are very close to those of frogs reported previously (Fatt and Katz, 1951; Koketsu and Nishi, 1957; Frank 1958).

Effect of stretch on the membrane constants. An example of the values of membrane constants of individual muscle fibres at $100 \%$ and $130 \%$ lengths is presented in table 4, which shows a wide variation among individual fibres, and it may be difficult to draw a conclusion from it. However, average values for each muscle presented in tables 2 and 3 show a tendency for $\lambda$ and $R_{m}$ to decrease with an increase in fibre length, but that effective resistance and $C_{m}$ increase. Although changes in $\lambda$ and $1 / 2\left(r_{m} r_{i}\right)^{1 / 2}$ are significant, the decrease in $R_{m}$ is not in most cases statistically significant, and the increase in $C_{m}$ is statistically significant only in 3 muscles out of 6 .

In table 5 the average of $C_{m}$ and $R_{m}$ of all muscle fibres for sartorius and iliofibular muscles are calculated. In these collected averages $C_{m}$ increases by $12-15 \%$, which is highly significant $\left(0.1 \%\right.$ level), while the decrease of $R_{m}$ is significant for sartorius muscle and probably significant for iliofibular muscle.

However, one cannot easily accept the conclusion drawn from this statistical treatment that $C_{m}$ increases and $R_{m}$ decreases significantly by application of stretch, because, for evaluating such a small difference of $C_{m}$ as about $15 \%$, errors involved in the measurements of fibre diameter and of the temperature of Ringer bath, and in the assumption of $R_{i}$ value are too great.

On the other hand, if one assumes that the muscle fibre consists of the material enveloped by a thin uniform sheet of membrane, the volume of both being independent of the length, the conductance of membrane per unit area 
TABLE 4. Membrane Constants of Individual Muscle Fibres of $M$. iliofibularis

\begin{tabular}{|c|c|c|c|c|c|c|c|c|c|}
\hline $\begin{array}{c}\text { Stretch } \\
(\%)\end{array}$ & $\begin{array}{l}\text { No. of } \\
\text { fibres }\end{array}$ & $\begin{array}{r}d \\
(\mu)\end{array}$ & $\begin{array}{l}\frac{1}{2}\left(r_{m} r_{i}\right)^{1 / 2} \\
\left(\times 10^{3} \Omega\right)\end{array}$ & $\begin{array}{c}\lambda \\
(\mathrm{mm} .)\end{array}$ & $\begin{array}{c}\tau_{\mathrm{m}} \\
\text { (msec.) }\end{array}$ & $\begin{array}{c}r_{\mathrm{m}} \\
\left(\times 10^{3} \Omega / \mathrm{cm}\right.\end{array}$ & $\begin{array}{c}r_{i} \\
\left(\times 10^{3} \Omega / \mathrm{cm} .\right.\end{array}$ & $\begin{array}{c}R_{m} \\
\left(\Omega \cdot \mathrm{cm}^{2} .\right.\end{array}$ & $\begin{array}{c}C_{m} \\
\left(\mu \mathrm{F} / \mathrm{cm}^{2} .\right)\end{array}$ \\
\hline \multirow{3}{*}{100} & \multirow{3}{*}{13} & $\begin{array}{l}68 \\
61 \\
65 \\
61 \\
54\end{array}$ & $\begin{array}{l}275 \\
264 \\
177 \\
263 \\
266\end{array}$ & $\begin{array}{l}2.2 \\
1.7 \\
1.3 \\
1.7 \\
1.3\end{array}$ & $\begin{array}{l}19.9 \\
20.8 \\
14.9 \\
17.0 \\
17.6\end{array}$ & $\begin{array}{r}120 \\
89 \\
46 \\
89 \\
77\end{array}$ & $\begin{array}{l}2480 \\
3080 \\
2720 \\
3080 \\
3940\end{array}$ & $\begin{array}{r}2820 \\
1700 \\
940 \\
1700 \\
1300\end{array}$ & $\begin{array}{l}7 \\
12 \\
16 \\
10 \\
13.5\end{array}$ \\
\hline & & $\begin{array}{l}54 \\
65 \\
68 \\
61 \\
61\end{array}$ & $\begin{array}{l}228 \\
280 \\
278 \\
460 \\
293\end{array}$ & $\begin{array}{l}1.4 \\
2.1 \\
2.2 \\
3.0 \\
1.9\end{array}$ & $\begin{array}{l}16.8 \\
19.0 \\
16.6 \\
16.7 \\
18.0\end{array}$ & $\begin{array}{r}77 \\
120 \\
120 \\
277 \\
111\end{array}$ & $\begin{array}{l}3940 \\
2720 \\
2480 \\
3080 \\
3080\end{array}$ & $\begin{array}{l}1300 \\
2450 \\
2560 \\
5300 \\
2130\end{array}$ & $\begin{array}{l}13 \\
8 \\
6.5 \\
3 \\
8\end{array}$ \\
\hline & & $\begin{array}{l}61 \\
68 \\
65\end{array}$ & $\begin{array}{l}293 \\
236 \\
300\end{array}$ & $\begin{array}{l}1.9 \\
1.5 \\
2.2\end{array}$ & $\begin{array}{l}16.9 \\
16.3 \\
15.8\end{array}$ & $\begin{array}{r}111 \\
56 \\
132\end{array}$ & $\begin{array}{l}3080 \\
2480 \\
2720\end{array}$ & $\begin{array}{l}2130 \\
1200 \\
2700\end{array}$ & $\begin{array}{r}8 \\
14 \\
6\end{array}$ \\
\hline \multicolumn{2}{|c|}{ Mean } & 62 & 278 & 1.9 & 17.4 & 110 & 2990 & 2170 & 9.6 \\
\hline \multirow[t]{2}{*}{130} & \multirow[t]{2}{*}{10} & $\begin{array}{l}54 \\
48 \\
54 \\
54 \\
54\end{array}$ & $\begin{array}{l}490 \\
490 \\
340 \\
303 \\
260\end{array}$ & $\begin{array}{l}2.6 \\
2.0 \\
1.8 \\
1.6 \\
1.4\end{array}$ & $\begin{array}{l}16.6 \\
13.9 \\
20.0 \\
19.5 \\
18.2\end{array}$ & $\begin{array}{r}259 \\
198 \\
124 \\
98 \\
77\end{array}$ & $\begin{array}{l}3830 \\
4950 \\
3830 \\
3830 \\
3830\end{array}$ & $\begin{array}{l}4400 \\
3000 \\
2100 \\
1660 \\
1300\end{array}$ & $\begin{array}{l}4 \\
5 \\
9.5 \\
12 \\
14\end{array}$ \\
\hline & & $\begin{array}{l}48 \\
51 \\
53 \\
58 \\
54\end{array}$ & $\begin{array}{l}250 \\
470 \\
226 \\
298 \\
262\end{array}$ & $\begin{array}{l}1.0 \\
2.1 \\
1.1 \\
1.8 \\
1.4\end{array}$ & $\begin{array}{l}14.2 \\
18.6 \\
14.6 \\
18.8 \\
17.7\end{array}$ & $\begin{array}{r}49 \\
194 \\
50 \\
104 \\
75\end{array}$ & $\begin{array}{l}4950 \\
4400 \\
4100 \\
3400 \\
3830\end{array}$ & $\begin{array}{r}750 \\
3100 \\
830 \\
1900 \\
1280\end{array}$ & $\begin{array}{r}19 \\
6 \\
19 \\
10 \\
14\end{array}$ \\
\hline \multicolumn{2}{|c|}{ Mean } & 53 & 339 & 1.7 & 17.2 & 123 & 4095 & 2030 & 11.2 \\
\hline
\end{tabular}

The temperature was $26^{\circ} \mathrm{C}$, and $R_{i}$ is assumed to be $90 \Omega \mathrm{cm}$.

TABLE 5. Collected Results

\begin{tabular}{|c|c|c|c|c|}
\hline Musle & $\begin{array}{c}\text { Stretch } \\
(\%)\end{array}$ & $\begin{array}{c}\text { Number of } \\
\text { muscle fibres }\end{array}$ & $\begin{array}{c}R_{m} \\
\left(\Omega \cdot \mathrm{cm}^{2} .\right)\end{array}$ & $\begin{array}{c}C_{m} \\
\left(\mu \mathrm{F} / \mathrm{cm}^{2} .\right)\end{array}$ \\
\hline Sartorius & $\begin{array}{c}100 \\
130 \\
t \text {-test }\end{array}$ & $\begin{array}{l}29 \\
30\end{array}$ & $\begin{array}{c}1879 \pm 57 \\
1644 \pm 33 \\
P<0.01\end{array}$ & $\begin{array}{l}6.1 \pm 0.09 \\
7.0 \pm 0.12 \\
P<0.001\end{array}$ \\
\hline Iliofibularis & $\begin{array}{c}100 \\
130 \\
t \text {-test }\end{array}$ & $\begin{array}{l}40 \\
33\end{array}$ & $\begin{array}{c}2486 \pm 43 \\
2365 \pm 36 \\
P<0.05\end{array}$ & $\begin{array}{r}9.7 \pm 0.09 \\
10.9 \pm 0.14 \\
P<0.001\end{array}$ \\
\hline \multicolumn{2}{|c|}{ Extens. digit. long. IV } & 28 & $3234 \pm 63$ & $6.6 \pm 0.14$ \\
\hline
\end{tabular}

\pm S.E. of the mean.

$\left(1 / R_{m}\right)$ will be proportional to the square root of the fibre length $(l)$, or inversely proportional to fibre diameter. Transverse capacitance of membrane per unit area $\left(C_{m}\right)$ is inversely proportional to the membrane thickness $(\delta)$. If the membrane is of constant volume, $\delta$ will vary as $l^{1 / 2}$, and therefore $C_{m}$ is proportional to $l^{1 / 2}$, or inversely proportional to $d$. Therefore, 


$$
R_{m}(130 \%)=\frac{1}{1.14} R_{m}(100 \%) \text { and } C_{m}(130 \%)=1.14 C_{m}(100 \%) .
$$

This calculation shows that by application of $130 \%$ stretch on the muscle the increase of $C_{m}$ and decrease of $R_{m}$ are only 14\%. Although this agrees with the difference of averages of collected results in table 5 (12-15\% increase in $C_{m}$ and 5-12\% decrease in $R_{m}$ ), errors involved in the measurement of these constants are too great to warrant the conclusion that $C_{m}$ increases and $R_{m}$ decreases by about $14 \%$ with a stretch of $130 \%$.

Membrane constants of various muscle fibres of different diameter. In earlier investigations $\mathrm{Katz}(1948,1949)$ obtained $4.5 \mu \mathrm{F} / \mathrm{cm}^{2}$. for $C_{m}$ of the muscle fibres of $45 \mu$ in diameter, $6 \mu \mathrm{F} / \mathrm{cm}^{2}$. for those of $75 \mu$; and Fatt and Katz (1951) reported $8 \mu \mathrm{F} / \mathrm{cm}^{2}$. for $C_{m}$ of muscle fibres of $137 \mu$. In table 5 average values of $C_{m}$ of three muscles do not change according to the diameter of the muscle fibre, although $R_{m}$ increases with the decrease in diameter. However, this change in $R_{m}$ may possibly be due to that of the experimental conditions, because (i) the experiments of the toe muscle, which gives the highest $R_{m}$ value, are carried out under the lowest temperature, and (ii) the experiments on the sartorius muscle, which gives the lowest $R_{m}$ value, are carried out with the two microelectrodes method, which might have caused a depolarization of the membrane (Fatt and Katz, 1951; Ishiko, 1957) and consequently a smaller $R_{m}$ value. Therefore from the results shown in table 5 it seems unlikely that there is a systematic change in $R_{m}$ with the change in the diameter of the muscle fibre when different muscles are compared. However, in order to get a definite conclusion, further accurate experiments to cover a wide range of the diameter of the muscle fibres are necessary.

\section{DISCUSSION}

The present experiments do not give conclusive evidence that the membrane capacitance and conductance increase significantly by application of stretch on the muscle fibre, because considerable errors are involved in measuring these constants. However, a tendency for both constants to increase by adout 10-15\% with $130 \%$ stretch, has been observed. Evidence supporting a change of $1 / R_{m}$ with stretch can partly be supplied by Ishiko's experiments $(1957,1958)$, in which it is shown that the resting potential is reduced by $3-4 \mathrm{mV}$ by stretching the muscle by about $130 \%$. There is at the moment no other definite evidence suggesting the conductance increase of the muscle fibre membrane with stretch, but Harris $(1953,1954)$ found a decrease in the cellular content of $\mathrm{Na}$ and no significant change in $\mathrm{K}$ by application of stretch. If a decrease in the $\mathrm{Na}$ content of the muscle fibre during stretch indicates the permeability increase of the membrane for sodium ions, this would sppear as a reduction in the resting potential and as a rise in the membrane conductance.

Recent experiments with single isolated muscle fibres by Hakansson (1957) have revealed that the conduction velocity remained unaltered up to a stretch of about $50 \%$ of the equilibrium length, and that it increased with further 
elongation. According to Offner, Weinberg and Young (1940) conduction velocities of similarly constructed non-medullated fibres and muscle fibres, which produce the same inward current density during excitation, are related as $\left(d / R_{i}\right)^{1 / 2} \times C_{m}^{-1}$. However, as seen in the present experiments $C_{m}$ does not change significantly, or changes only by about $12-15 \%$ in proportion to $d^{1 / 2}$. Therefore such a significant change in the conduction velocity as reported by Hakansson cannot be expected merely from a change in $C_{m}$. The only possible cause of the increase in the conduction velocity is a decrease in the threshold current of the muscle fibre membrane with stretch, because it is reduced by about $40-50 \%$ with a stretch of $130 \%$ (Ishiko, 1957), but the magnitude of the action potential does not change.

This reduction of about $50 \%$ in the threshold current with a $130 \%$ stretch might be explained by both an increase in the effective resistance and an decrease in the resting potential or threshold depolarization potential. For example, if one assumes that the sartorius muscle fibres, having a resting potential of $80 \mathrm{mV}$, initiate an action potential when they are depolarized by $20 \mathrm{mV}$, the threshold current should roughly be $20 \times 10^{-3} \mathrm{~V} / 130 \times 10^{3} \Omega=1.5 \times$ $10^{-7}$ A (e.g. muscle $A$ of table 2); when the muscle fibre is stretched to $130 \%$ of the normal length, it should initiate an impulse with a depolarization of 16 $17 \mathrm{mV}$, because its resting potential is reduced by $3-4 \mathrm{mV}$, and therefore its threshold current will become $(16-17) \times 10^{-3} \mathrm{~V} / 160 \times 10^{3} \Omega=1 \times 10^{7} \mathrm{~A}$. Thus from this approximate calculation it is shown that the threshold current is reduced by about $50 \%$ when a muscle fibre is stretched from $100 \%$ to $130 \%$ length.

\section{SUMMARY}

The membrane constants of muscle fibres of toads, in normal and stretched states, were measured by square pulse analysis. A tendency for both $C_{m}$ and $1 / R_{m}$ to increase by the application of stretch was observed, but the difference of these constants between relaxed and stretched states is so small that it cannot be considered significant by taking into consideration various errors involved in measuring these constants. However, other kinds of experiments on muscle fibres would support the conclusion that $C_{m}$ and $1 / R_{m}$ increase, although this increase is only about $14 \%$.

The authors are indebted to $\mathrm{Mr}$. M Ozeki for his kind help in some of the experiments, to Dr. M. Ito for his kind advice in preamplifier circuit, and to Dr. D. Wilkie for reading this manuscript.

\section{REFERENCES}

1. EDDY, N. B. AND Downs, A. W. Extensibility of muscle: the production of carbon dioxyde by a muscle when it is made to support a weight. Amer. J. Physiol. 56: 188195, 1921.

2. PATT, P. AND KATz, B. An analysis of the endplate potential recorded with an intra-cellular electrode. J. Physiol. 115: 320-370, 1951. 
3. Feng, T. P. Effect of length on muscle metabolism. J. Physiol. 74: 441-454, 1932.

4. FRANK, G. B. Effect of veratrine on muscle fibre membrane and on negative afterpotential. J. Neurophysiol. 21: 263-278, 1958.

5. HÅkANSSON, C. H. Action potential and mechanical response of isolated cross striated frog muscle fibres at different degree of stretch. Acta Physiol. Scand. 41: 199-216, 1957.

6. HARris, E. J. The exchange of frog muscle potassium. J. Physiol. 120: 246-253, 1953.

7. HARRIS, E. J. An effect of stretch upon the sodium output from frog muscle. J. Physiol. 124: 242-247, 1954.

8. Hodgkin, A. L. And Rushton, W. A. H. The electrical constants of a crustacean nerve fibre. Proc. Roy. Soc. B, 133: 444-479, 1946.

9. InOUE, F. Conduction velocity of action potential in a striated muscle fibre. Natur. Sci. Rep. Ochanomizu Univ. 5: 284-290, 1955.

10. Isнiко, N. The effect of stretch on electrical properties of striated muscle fibres. Kumamoto Med. J. 10: 199-207, 1957.

11. Isнiко, $\mathrm{N}$. Changes in resting and action potentials of striated muscle fibres by stretch. Kumamoto Med. J. 11: 18-31, 1958.

12. ITO, M. The electrical activity of spinal ganglion cells investigated with intracellular microelectrodes. Jap. J. Physiol. 7: 297-323, 1957.

13. Iто, M. A microelectrode investigation into a toad's spinal ganglion cell. Seitai no Kagaku, 20: 12-20, 1958.

14. KATZ, B. The electrical properties of the muscle fibre membrane. Proc. Roy. Soc. B, 135: 506-534, 1948.

15. KAtz, B. Les constantes élèctriques de la membrane du muscle. Arch. Sci. Physiol. 3: 285-299, 1949.

16. KoKETSI, K. AND NISHI, S. An analysis of junctional potentials of intrafusal muscle fibres. J. Physiol. 139: 15-26, 1957.

17. LING, G. AND GERARD, R. W. The influence of stretch on the membrane potential of the striated muscle fibre. J. cell. comp. Physiol. 34: 397-405, 1949.

18. MACNICHOL, E. F. A high-impedance input circuit suitable for electrophysiological recording from micropipette electrodes. Nav. Med. Resear. Inst. 97-117, 1954.

19. MARTIN, A. R. The effect of change in length on conduction velocity in muscle. $J$. Physiol. 125: 215-220, 1954.

20. OFFNER, F., WeInBERG, A. AND YounG, G. Nerve conduction theory: some mathematical consequences of Bernstein's model. Bull. math. Biophys. 2: 89-103, 1940.

21. TAMASige, M. Membrane and sarcoplasm resistance in an isolated frog muscle fibre. Annot. Zool. Jap., 23: 125-134, 1950.

22. Wilska, A. AND VARJORANTA, K. Untersuchungen über die Geschwindigkeit des geleiteten Aktionspotentials einer Muskelfaser bei verschiedenen Dehnungszustanden des Muskels. Skand. Arch. Physiol., 83: 82-87, 1940.

23. YoshidA, R. Electrophysiological studies on two kinds of skeletal muscle fibres of the toad's geniohyoideus muscle. J. Physiol. Soc. Jap. 20: 129-142, 1958. 